Jurnal Pendidikan Dasar, 6 (1) Juni 2018

\title{
MENUMBUHKAN KETERAMPILAN BERBICARA MENGGUNAKAN MODEL TIME TOKEN PADA SISWA KELAS III SDN 13 POPAI
}

\author{
Tanti Widiyasari ${ }^{1}$, Ason $^{2}$, Septian Peterianus ${ }^{3}$ \\ ${ }^{1}$ Mahasiswa Lulusan Program Studi PGSD Tahun 2017 \\ ${ }^{2,3}$ Dosen STKIP Melawi
}

Jl. RSUD Melawi km. 04 Kec. Nanga Pinoh Kab. Melawi Kalimantan Barat widiyasaritanti11@gmail.com, asonstkip@yahoo.com, adja_tian@ymail.com

\begin{abstract}
This classroom action research aims to determine the growth of speaking skills with Time Token model model. To facilitate the used in applying the Time Token model on the students of class III SDN 13 Popai. The research method used is descriptive method, with type of classroom action research (PTK) which in Kemmis Mc Taggart model. This research is conducted in two cycles, each cycle is divided into 4 steps, consisting of planning, action implementation, observation, and reflection. Data collecting. The technique data used is the observation sheet. The research data is described through the table to see the growth of language skills that are quantitative. The result of this research can be seen by used Time Token model to grow the language training for Indonesian class III SDN13 Popai students. Language equation in cycle I is $66.67 \%$, in cycle II to $87.5 \%$, increase of $20.83 \%$.
\end{abstract}

Keyword: Student Speaking Study, Token Time Model.

\begin{abstract}
Abstrak: Penelitian ini bertujuan untuk mengetahui tumbuhnya keterampilan berbicara siswa dengan penerapan model Time Token. Secara khusus penelitian ini bertujuan untuk mendeskripsikan tumbuhnya keterampilan berbicara siswa dengan penerapan model Time Token pada siswa kelas III SDN 13 Popai. Metode penelitian yang digunakan adalah metode deskriptif, dengan jenis penelitian tindakan kelas (PTK) yang mengacu pada model Kemmis Mc Taggart Penelitian ini dilaksanakan dalam dua siklus, setiap siklus terbagi menjadi 4 langkah, terdiri dari perencanaan, pelaksanaan tindakan, pengamatan, dan refleksi. Data yang dikumpulkan berupa nilai keterampilan berbicara siswa. Teknik pengumpulan data yang digunakan adalah lembar observasi keterampilan berbicara. Data penelitian dideskripsikan melalui tabel untuk melihat tumbuhnya keterampilan berbicara siswa yang bersifat kuantitatif. Hasil penelitian dapat dilihat apakah penerapan model Time Token dapat menumbuhkan keterampilan berbicara pada pembelajaran Bahasa Indonesia siswa kelas III SDN 13 Popai. Keterampilan berbicara siswa pada siklus I sebesar 50\%, pada siklus II menjadi $79.16 \%$, mengalami peningkatan sebesar 29.16\%.
\end{abstract}

Kata Kunci: Keterampilan Berbicara Siswa, Model Time Token.

$\mathrm{D}$ alam konteks pembelajaran bahasa untuk meningkatkan kemampuan siswa Indonesia di Sekolah Dasar, berkomunikasi dalam bahasa Indonesia pembelajaran bahasa Indonesia diarahkan dengan baik dan benar, baik secara lisan 
maupun tulisan serta menumbuhkan apresiasi terhadap hasil karya kesastraan Indonesia. Keterampilan berbicara harus dikuasai oleh para siswa Sekolah Dasar karena keterampilan ini secara langsung berkaitan dengan seluruh proses belajar siswa di sekolah dasar.

Keberhasilan belajar siswa dalam mengikuti proses kegiatan belajar mengajar di Sekolah sangat ditentukan oleh penguasaan kemampuan berbicara mereka. Siswa yang tidak mampu berbicara dengan baik dan benar akan mengalami kesulitan dalam mengikuti kegiatan pembelajaran untuk semua mata pelajaran. Selain itu, dengan kemampuan berbicara bahasa Indonesia dengan baik dan benar memudahkan siswa untuk berkomunikasi dan mengungkapkan ide atau gagasan kepada orang lain.

Ketika melaksanakaan observasi dan wawancara di SDN 13 Popai Kabupaten Melawi pada tanggal 7 Februari 2017, peneliti mendapati bahwa: Pertama, saat berbicara sebagian siswa masih menggunakan antara Bahasa Indonesia dengan Bahasa Daerah ketika berbicara sehingga menjadi kendala saat guru harus mengajar. Kedua, siswa sudah berani maju saat ditunjuk ke depan kelas dan membaca teks bacaan yang guru berikan, namun saat siswa ditanyai tentang pendapatnya dan berbicara langsung di depan kelas siswa masih belum percaya diri dan gugup.
Ketiga, kurangnya rasa ingin tahu siswa saat guru menjelaskan di dalam kelas dan malu untuk bertanya berkaitan dengan materi yang guru jelaskan. Keempat, masih kurangnya sifat inisiatif dan partisipatif yang siswa miliki.

Mengatasi permasalahan tersebut peneliti melakukan penelitian tindakan kelas khusunya pada mata pelajaran Bahasa Indonesia, peneliti berupaya untuk menerapkan Model pembelajaran Time Token agar mampu menumbuhkan keterampilan berbicara siswa, khususnya pada siswa kelas III SD Negeri 13 Popai pada mata pelajaran seni budaya. 1) Kelebihan dari strategi ini adalah: Mendorong siswa untuk meningkatkan inisiatif dan partisipasinya. 2) Siswa tidak mendominasi pembicaraan atau diam sama sekali. 3) Siswa menjadi aktif dalam kegiatan pembelajaran.

Terkait dengan uraian di atas maka peneliti akan melakukan sebuah penelitian tindakan kelas dengan judul "Menumbuhkan keterampilan berbicara mata pelajaran Bahasa Indonesia menggunakan model pembelajaran Time Token pada siswa kelas III SDN 13 Popai" Penelitian akan dilakukan di kelas III SDN 13 Popai, kecamatan Ella Hilir Kabupaten Melawi.

\section{METODE PENELITIAN}

Jenis penelitian yang dilakukan adalah penelitian tindakan kelas yang dilaksanakan dalam beberapa siklus, yaitu siklus I dan 25| J P D, p-IS S N : 2252 - 8156 , e - I S S N : $2579-3993$ 
seterusnya. Tahap-tahap penelitian dan refleksi), keempat komponen tersebut menggunakan model Kemmis dan Mc digambarkan sebagai berikut:

Taggart, dalam pelaksanaan meliputi perencanaan, pelaksanaan tindakan, observasi, dan refleksi. (Kemmis dan Mc Taggart dalam Arikunto, 2010: 137-140).

Subjek dalam penelitian ini adalah siswa dan guru kelas III SDN 13 Popai. Jumlah siswa yang menjadi subjek penelitian adalah 24 siswa dengan rincian 13 laki-laki dan 11 perempuan. Objek dari penelitian ini adalah keterampilan berbicara siswa. Objek yang difokuskan pada 1) Ketepatan Ucapan. 2) Pilihan Diksi (Kata). 3) Pandangan harus diarahkan pada lawan bicara. 4) Kenyaringan Suara dan 5) Penguasaan Topik dalam proses belajarmengajar khususnya pada mata pelajaran Bahasa Indonesia. Pelaksanan penelitian direncanakan pada bulan Juni 2017, semester genap tahun pelajaran 2017/2018. Proses penelitian tindakan kelas merupakan kerja berulang atau siklus, sehingga diperoleh pembelajaran yang dapat membantu siswa dalam menyelesaikan masalah yang terjadi saat pembelajaran berlangsung.

Prosedur penelitian menggunakan model PTK dengan Model KemmisMc Taggart. Menurut Kemmis danMc Taggart (Arikunto, 2010: 137-140) mereka menggunakan empat komponen penelitian tindakan (perencanaan, tindakan, observasi,

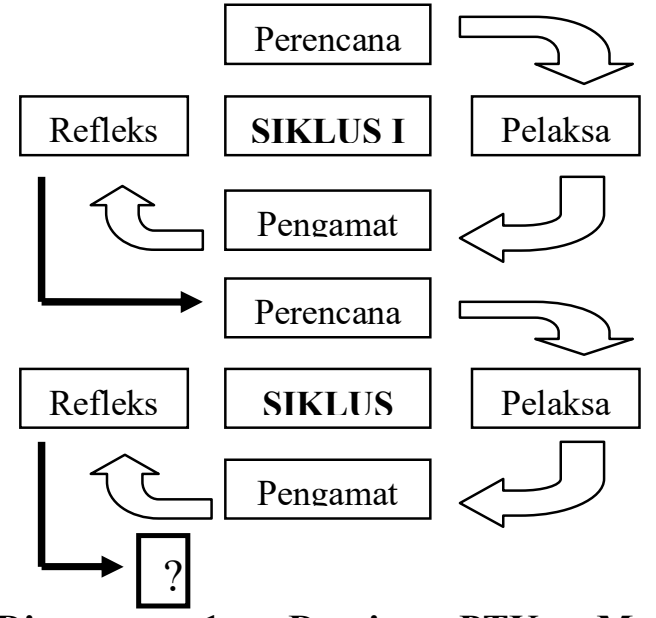

Diagram 1. Desain PTK Model KemmisMc Taggart

Setiap siklus terdiri atas perencanaan, pelaksaaan, observasi dan refleksi. Siklus I dapat dilanjutkan dengan Siklus II, apabila kemampuan berpikir kritis siswa belum mencapai kriteria keberhasilan yang telah ditentukan. Demikian selanjutnya siklus II dilanjutkan ke siklus III. Adapun rancangan pelaksanaan tindakan ini mengikuti tahaptahap penelitian tindakan kelas yang masingmasing siklus terdiri dari empat tahap yaitu sebagai berikut:

Perencanaan yaitu menyiapkan materi, membuat rencana pelaksanaan pembelajaran, menyiapkan media pembelajaran, menyiapkan soal tes akhir siklus, mendiskusikan RPP dengan observer, menyiapkan alat pengumpulan data berupa, lembar observasi keterampilan berbicara siswa dan lembar observasi keterlaksanaan kegiatan pembelajaran dan menyiapkan alat dokumentasi untuk 
kegiatan pembelajaran yang sedang berlangsung. Pelaksanaan tindakan ada tiga kegiatan yaitu kegiatan awal, kegiatan inti, dan kegiatan akhir. Pada kegiatan awal peneliti menyapa siswa, mengajak siswa berdo'a sebelum memulai pelajaran, mengabsen, dan mengajak iswa untuk melakukan game permainan yang dapat membuat siswa lebih semangat dan fokus dalam belajar. Pada tahap apersepsi peneliti sebagai pelaksana tindakan memberikan motivasi kepada seluruh siswa. Selanjutnya menyebutkan materi yang akan dipelajari dan menyampaikan tujuan pembelajaran. Kegiatan inti meliputi eksplorasi, elaborasi, dan konfirmasi. Pada kegiatan eksplorasi, peneliti menggali gagasan siswa mengenai definisi dari cerita, meminta siswa membaca bacaan "Pekerjaan Petani".

Pada kegiatan elaborasi, Guru menejelaskan tujuan pembelajaran/KD, Guru memberikan tugas kepada siswa (menggunakan metode pembelajaran cerita berantai guru meminta siswa bercerita secara bergantian sambung menyambung sesuai dengan isi teks yang telah mereka baca), guru membagikan sejumlah kupon berbicara dengan waktu kurang lebih 30 detik per kupon pada tiap siswa, guru meminta siswa menyerahkan kupon terlebih dahulu sebelum bebricara atau berkomentar. Hal tersebut secara terus menerus siswa lakukan hingga kupon yang mereka pegang telah habis. Selanjutnya guru memberikan nilai sesuai waktu yang mereka gunakan dan meminta siswa untuk berbicara menunjukkan kemampuannya sebaik mungkin.

Pada tahap observasi, peneliti berkerja sama dengan wali kelas III SDN 13 Popai. Peneliti sebagai pelaksana tindakan dan wali kelas sebagai observer atau pengamat, menilai keterlaksanaan kegiatan pembelajaran dengan menggunakan model pembelajaran Time Token, menggunakan lembar observasi keterlaksanaan pembelajaran yang sebelumnya telah dipersiapkan oleh peneliti. Pada tahap refleksi peneliti mencatat hal-hal yang perlu diperbaiki dan dikembangkan, maka dapat menentukan langkah selanjutnya. Jika hasil tindakan menunjukkan adanya peningkatan keterampilan bebricara yang sangat baik, misalnya siswa aktif dalam proses pembelajaran, siswa berbicara dengan menggunakan bahasa Indonesia yang baik dan benar dan siswa sudah tidak malu lagu untuk maju dan berbicara langsung ke depan kelas. Maka, tidak dilakukan tindakan berikutnya, tetapi jika hasil tindakan belum menunjukan adanya peningkatan keterampilan berbicara siswa, misalnya siswa kurang terlibat dalam proses pembelajaran serta kurang tertarik dalam mengikuti proses kegiatan belajar mengajar, maka akan dilanjutkan pada siklus II.

Data dalam penelitian ini adalah teknik analisis secara kuantitatif, teknis analisis 27| J P D, p-IS S N : $2252-8156$, e - I S S N : $2579-3993$ 
secara kuantitaif disajikan dalam bentuk kalkulasi terhadap skor yang diperoleh selama pengumpulan data, dan data yang diperoleh dari hasil observasi pada setiap siklus, dianalisis secara deskriptif dan disajikan dalam bentuk tabel untuk mengetahui keterampilan berbicara siswa selama penelitian. Apakah siswa memiliki keterampilan berbicara yang baik selama penelitian.

Analisis data observasi keterampilan berbicara siswa yaitu hasil tes, tes dilakukan untuk mengukur keterampilan bebricara siswa dalam pelajaran Bahasa Indonesia dengan model pembelajaran Time Token. Untuk mengetahui ada tidaknya peningkatan keterampilan berbicara siswa dilakukan dengan membandingkan hasil tes diakhir setiap siklus.

Hasil yang digunakan dalam penelitian ini adalah nilai akhir tes keterampilan berbicara siswa. Oleh karena itu penilaian keterampilan berbicara hasilnya berupa skor. Selanjutnya, skor yang siswa dapatkan dirubah ke dalam bentuk nilai.

\section{HASIL DAN PEMBAHASAN}

\section{Hasil}

Penelitian ini bertujuan untuk perkembangan kemampuan berpikir kritis siswa khususnya dalam pembelajaran bahasa Indonesia pada siswa kelas III SDN 13 Popai. Sebelum melaksanakan pembelajran dengan menggunakan model Time Token, guru dan peneliti mengadakan diskusi terlebih dahulu mengenai materi pembelajaran yang akan diajarkan kepada siswa, dan hal-hal yang berkaitan dengan pelaksanaan proses pembelajaran bahasa Indonesia sehingga pelaksanaan penelitian dapat berjalan sesuai yang diharapkan.

\section{Hasil Siklus I}

Hasil observasi siswa siklus I pertemuan I dan II, menunjukkan bahwa 16 orang siswa telah memenuhi kriteria keberhasilan, dengan persentase keberhasilan sebesar $\quad 66.67 \%$. Jumlah masing-masing kriteria terdiri dari kriteria sangat baik diperoleh 0 orang, kriteria baik diperoleh 1 orang, kriteria cukup baik diperoleh 15 orang, kriteria kurang baik diperoleh 8 orang dan kriteria sangat kurang baik diperoleh 0 orang. Dengan demikian dapat dikatakan bahwa siklus I belum berhasil maka akan dilanjutkan dengan siklus II.

\section{Hasil siklus II}

Hasil observasi siswa siklus II, menunjukkan bahwa 21 orang siswa telah memenuhi kriteria keberhasilan, dengan persentase keberhasilan sebesar $87.5 \%$. Jumlah masing-masing kriteria terdiri dari kriteria sangat baik diperoleh 1 orang, kriteria baik diperoleh 6 orang, kriteria cukup baik diperoleh 15 orang, kriteria kurang baik diperoleh 2 orang dan kriteria sangat kurang baik diperoleh 0 orang. Maka penelitian ini tidak dilanjutkan kembali atau dikatakan selesai. 


\section{Pembahasan}

Jumlah siswa kelas III SDN 13 Popai berjumlah 24 orang. Dalam empat kali pertemuan seluruh siswa selalu hadir, sehingga ke 24 siswa tersebut menjadi objek dalam penelitian yang peneliti lakukan. Proses penelitian pada siklus I, peneliti di bantu guru kelas sekaligus wali murid kelas III melakukan tindakan, dimana tindakan dilakukan dalam dua siklus dan tiap siklus terdapat dua pertemuan. Melalui model Time Token, peneliti dapat menumbuhkan keterampilan berbicara siswa dengan mengoptimalkan keaktifan siswa, dimana seluruh siswa terlibat dalam setiap proses pembelajaran sehingga proses pembelajaran bahasa Indonesia tidak bepusat pada guru.

Diketahui bahwa Time Token merupakan suatu model pembelajaran yang dapat melatih keterampilan sosial siswa, sehingga dalam proses pembelajaran semua siswa aktif berbicara tidak ada yang mendominasi pembicaraan atau diam sama sekali. (Huda, 2013: 211). Model ini menggunakan sebuah media berupa kupon berbicara yang memiliki nilai waktu berbicara kurang lebih 30 detik, setiap ingin berbicara siswa terlebih dahulu menyerahkan kuponnya. Oleh karena itu, melalui model Time Token guru dapat menciptakan proses belajar mengajar yang aktif, dapat melatih siswa untuk berani berkomunikasi dan mengungkapkan pendapatnya serta dapat melatih siswa untuk dapat menghormati pendapat orang lain.

Berdasarkan hasil pengamatan keterlaksanaan rencana kegiatan pembelajaran yang dilakukan oleh guru di sekolah tersebut yang bertugas sebagai observer, bahwa proses pembelajaran menggunakan model Time Token pada siklus I pertemuan pertama memperoleh hasil yang baik. Untuk kegiatan awal mendapat persentase $100 \%$ kegiatan awal yang dilakukan peneliti seperti membuka pelajaran dengan memberikan salam, mengabsen siswa, dan memberikan apersepsi materi atau motivasi yang akan dipelajari. Pada kegiatan inti mendapat persentase $70 \%$, tahap ini belum dapat terlaksana dengan maksimal, peneliti belum memberikan pelajaran dengan baik karena masih dalam tahap perkenalan dengan siswa. Saat peneliti mengajukan pertanyaan kepada siswa masih banyak yang terlihat takut atau ragu untuk menjawab, peneliti melupakan bagian saat siswa seharusnya membaca bacaan yang berjudul "Pekerjaan Petani" namun tidak peneliti laksanakan. Sedangkan pada kegiatan akhir sebagai penutup pelajaran mendapat persentase $75 \%$, tahap ini tidak terlalu sulit tetapi peneliti tidak melaksanakan penyimpulan materi yang telah dipelajari. Perolehan rata-rata yang didapat pada siklus I pertemuan pertama sebesar $81.67 \%$. 
Pada pertemuan kedua memperoleh hasil yang semakin baik, kegiatan yang dilaksanakan seperti pertemuan sebelumnya. Pada kegiatan awal mendapat persentase $100 \%$, peneliti masih kesulitan untuk mengatur kondisi kelas. Pada kegiatan inti mendapat persentase $80 \%$ peneliti masih belum dapat membuat siswa terbiasa melakukan proses pembelajaran yang menggunakan model Time Token, serta sebagian siswa juga masih belum berani untuk maju dan berbicara langsung di depan kelas menceritakan peristiwa yang pernah mereka lihat. Pada kegiatan akhir mendapat persentase cukup yakni sebesar 75\% karena peneliti tidak melaksanakan doa penutup karena kegiatan pembelajaran bahasa indonesia pada jam pertama. Perolehan ratarata yang didapat pada siklus I pertemuan kedua sebesar 85\%. Siklus I pertemuan pertama yang kemudian dilanjutkan kepertemuan kedua, mengalami peningkatan, pada kegiatan awal persentase tetap sebesar $100 \%$, pada kegiatan inti meningkat sebesar $10 \%$ menjadi $80 \%$, dan pada kegiatan akhir tidak ada peningkatan. Jadi pada siklus I keterlaksanaan proses pembelajaran memperoleh rata-rata sebesar $83.33 \%$.

Penelitian dilanjutkan pada siklus II, sebelum pembelajaran pada siklus II dimulai peneliti terlebih dahulu menyusun rencana sesuai hasil refleksi pada siklus I, yang bertujuan untuk memperbaiki pembelajaran sebelumnya. Perbaikan yang dilakukan diantaranya lebih mengontrol situasi kelas, serta lebih membimbing dan melibatkan siswa secara maksimal ketika pembelajaran berlangsung. Pada siklus II pertemuan pertama dan dilanjutkan pertemuan kedua mengalami peningkatan. Siklus II pertemuan pertama memperoleh persentase rata-rata sebesar $83.33 \%$, perolehan pada siklus II pertemuan pertama menunjukan adanya perubahan setelah dilakukan refleksi, selanjutnya pembelajaran diteruskan pada pertemuan kedua, dan memperoleh persentase sebesar $91.67 \%$.

Hasil keterampilan berbicara siswa dalam penelitian ini diperoleh melalui lembar observasi keterampilan berbicara siswa. Lembar observasi keterampilan berbicara siswa digunakan saat guru mengajar yang kemudian di isi oleh obersver yakni wali kelas III. Berdasarkan observasi keterampilan berbicara siswa, oleh peneliti pada kegiatan pembelajaran menggunakan model Time Token pada siklus I dan siklus II, siswa-siswa sudah berani berbicara langsung di depan kelas. Selain itu, siswasiswa juga sudah berani maju kedepan kelas tanpa ada rasa malu atau takut lagi, cara berbicara siswa juga sudah menunjukkan jika sedikit demi sedikit siswa mampu berbicara bahasa Indonesia yang baik dan benar serta mulai memperhatikan guru saat mengajar, mayoritas siswa tidak bermain dan berbicara sendiri ketika guru 30| J P D, p-IS S N : 2252 - 8156 , e - I S S N : 2579 - 3993 
menjelaskan materi meskipun masih terdapat satu-dua siswa yang perhatiannya tidak fokus.

Hasil keterampilan berbicara siswa pada siklus I pertemuan pertama dan kedua menunjukkan siswa kelas III yang memperoleh skor keterampilan berbicara $\geq 70$ terdapat $66.67 \%$ (16 siswa) dari jumlah siswa kelas III, hal tersebut belum memenuhi kriteria keberhasilan dalam penelitian ini yaitu $80 \%$ siswa kelas III memperoleh skor keterampilan berbicara dalam kriteria keterampilan berbicara dengan batas minimal skor keterampilan berbicara siswa sebesar 70 disetiap siklusnya.

Oleh karena itu peneliti memutuskan untuk melakukan tindakan lagi untuk melakukan rekomendasi berupa solusi-solusi yang telah direncanakan pada tahap refleksi di siklus I guna memperbaiki kendalakendala yang dihadapi pada siklus I. Pada siklus II, keterampilan berbicara siswa meningkat sebesar $20.83 \%$ menjadi $87.5 \%$ (21 siswa). Hal tersebut menunjukkan bahwa pada siklus II kriteria keberhasilan penelitian sudah tercapai.

Dalam pelaksanaan tindakaan di siklus II ini selain terjadi pertumbuhan keterampilan berbicara siswa, hasil refleksi siklus I yang dihadapi pada siklus II sudah mulai nampak hasilnya dengan rekomendasi yang telah direncanakan pada refleksi siklus I. Siswa mulai berani untuk maju dan berbicara langsung di depan kelas. Selain itu, guru sudah mengoptimal waktu sehingga seluruh siswa dapat berbicara secara bergantian. Guru juga sudah mulai tegas kepada siswa sehingga siswa tidak asyik bermain sendiri atau mengobrol dengan teman sebangkunya. Tetapi pada siklus II terdapat lima siswa yang mengalami penurunan dan ketetapan skor keterampilan berbicara. Siswa yang menglami peningkatan drastis yaitu NS, MI dan NSI mengalami peningkatan hasil observasi keterampilan berbicara pada aspek keterlibatan siswa dalam kegiatan belajar mengajar. Ketiga siswa tersebut ketika tindakan pada siklus II, aktif, berani maju kedepan kelas, percaya diri dalam berbicara dan kegiatan tanya jawab. Sedangkan siswa yang tidak mengalami peingkatan skor keterampilan berbicara yaitu AS, SH dan YS ketiga siswa tersebut medapatkan kriteria nilai cukup baik, mereka sudah berani untuk maju dan berbicara, namun siswa tersebut cenderung tidak fokus dan serius saat berbicara sehingga ada beberapa aspek keterampilan berbicara yang tidak mereka penuhi, hal tersebutlah yang menyebabkan nilai ke tiga siswa tersebut tidak mengalami peningkatan.

\section{SIMPULAN}

Berdasarkan hipotesis tindakan, pada akhirnya melalui Model Pembelajaran Time Token keterampilan berbicara siswa dalam pembelajaran bahasa Indonesia di kelas III 31| J P D, p - I S S N : 2252-8156, e - I S S N : $2579-3993$ 
SDN 13 Popai dapat ditingkatkan menjadi lebih baik. Berdasarkan hasil penelitian yang telah dibahas dan dianalisis sebelumnya pada siklus I dan siklus II maka peneliti dapat menyimpulkan bahwa:n Adanya peningkatan kualitas proses pembelajaran dengan kesesuaian perencanaan pada RPP siklus I yaitu $83.33 \%$ dan siklus II yaitu $91.67 \%$, peningkatan yang terjadi antara siklus I dan siklus II yaitu sebesar $8.34 \%$. Adanya pertumbuhan keterampilan berbicara dari masing-masing siswa dari siklus I ke siklus II yaitu dengan presentase klasikal siklus I $66.67 \%$ dan presentase klasikal siklus II yaitu $87.5 \%$, peningkatan yang terjadi antara siklus I dengan siklus II yaitu sebesar 20.83\%. Peningkatan dari siklus I ke siklus II telah memenuhi kriteria keberhasilan dalam penelitian ini.

\section{Daftar Pustaka}

Arikunto, S. 2009. Penelitian Tindakan Kelas. Jakarta: Bumi Aksara.

Arikunto, S. 2010. Prosedur Penelitian. Jakarta: Rineka cipta.

Huda, M. 2014. Model-model Pengajaran dan Pembelajaran. Yogyakarta: Pustaka Pelajar.

Purwoko, A. 2001. Panduan Penelitian PTK. Semarang: Uness press.

Susanto, A. 2013. Teori Belajar dan Pembelajaran. Jakarta: Fajar Interpratama Mandiri.
Zuriah, N. 2009. Metodologi Penelitian Sosial Dan Pendidikan. Jakarta: Bumi Aksara. 